\title{
BRS FC406: COMMON BEAN CULTIVAR WITH HIGH YIELD IN THE RAINY SEASON IN CENTRAL BRAZIL
}

\author{
Helton Santos Pereira *, (D) Thiago Lívio Pessoa Oliveira de Souza ${ }^{1}$, (D) Luís \\ Cláudio de Faria ${ }^{1}$, (D) Marcelo Sfeir Aguiar ${ }^{1}$, (iD Adriane Wendland ${ }^{1}$, (D) Joaquim \\ Geraldo Cáprio da Costa ${ }^{1}$, (iD José Luiz Cabrera Díaz ${ }^{1}$, (iD Mariana Cruzick de Souza \\ Magaldi $^{1}$, (D) Nilda Pessoa de Souza ${ }^{1}$, (D) Hélio Wilson Lemos de Carvalho ${ }^{2}$, \\ Antônio Félix da Costa $^{3}$, (iD Carlos Lásaro Pereira de $\mathrm{Melo}^{4}$, (iD) Válter Martins de \\ Almeida $^{5}$, (D) Leonardo Cunha Melo ${ }^{1}$ \\ 1 Embrapa Arroz e Feijão, Santo Antônio de Goiás, GO, Brazil; \\ 2 Embrapa Tabuleiros Costeiros, Aracaju, SE, Brazil; \\ 3 Instituto Agronômico de Pernambuco - IPA, Recife, PE, Brazil; \\ 4 Embrapa Soja, Londrina, PR, Brazil; \\ 5 Empresa Mato-grossense de Pesquisa, Assistência e Extensão Rural, Cuiabá, MT, Brazil. \\ * Corresponding author: Helton Santos Pereira (helton.pereira@embrapa.br).
}

\begin{abstract}
BRS FC406 is a common bean cultivar with excellent seed size and yields in the rainy season in central Brazil, i.e, 19\% more than BRS Estilo. It has a normal cycle, a mean yield of $2464 \mathrm{~kg} \mathrm{ha}^{-1}$, a high yield potential (4472 $\left.\mathrm{kg} \mathrm{ha}^{1}\right)$, and is resistant to anthracnose and angular leaf spot.
\end{abstract}

Keywords: Phaseolus vulgaris, angular leaf spot, anthracnose.

\section{Introduction}

At a global level, Brazil is one of the main common bean (Phaseolus vulgaris L.) producers and consumers (FAO, 2020). The crop has a high socioeconomic value, for being used by small, medium, and large producers distributed across a major part of the national territory. In Brazil, common bean can be planted in three main growing seasons (dry, rainy, and winter). Approximately $75 \%$ of the common bean produced and consumed in Brazil belongs to the carioca bean (cream with brown stripes) class (Melo et al., 2017).

In view of the high relevance of the crop, common bean breeding programs of public and private research institutions in Brazil have continuously supplied the domestic market with new cultivars. These programs prioritize desirable traits such as disease resistance, low loss when harvested mechanically, earliness, and higher yield potential and stability. The efforts have led to a yield increase from $810 \mathrm{~kg} \mathrm{ha}^{-1}$ in 2000 to $1,550 \mathrm{~kg} \mathrm{ha}^{-1}$ in 2017 (Embrapa Arroz e Feijão, 2019), i.e., a mean increase of $91 \%$. The genetic gains in common bean yield as a result of breeding by Embrapa are of the order of $0.72 \%$ per year for the carioca market class (Faria et al., 2013).

The low seed use index makes bean cultivars broadly adaptable, thus widening the yield range and generating economic returns for seed producers. However, cultivars can and 
should be recommended for specific environments, based on the effect of the genotypeenvironment interaction. Therefore, in the last years, a diversification of the range of cultivars has been addressed, positioning them more specifically in terms of ideal planting regions and growing seasons. For example, cultivar BRS Estilo (Melo et al., 2010) is suited for cultivation in the rainy and dry seasons, due to the more upright growth and lighter seeds, whereas BRS FC402 (Melo et al., 2017) is adequate for cultivation in the winter, due to the high resistance to anthracnose and soil diseases. BRS Notável is indicated for cultivation with low technological standard, because it is resistant to several diseases, e.g., anthracnose, fusarium wilt, common bacterial blight, and bacterial wilt (Pereira et al., 2012). BRS Sublime is appropriate for regions with high incidence of angular leaf spot, to which it is highly resistant (Wendland et al., 2018).

\section{Breeding methods}

BRS FC406 was derived from the lines FEB 212 and VAX 4, crossed at CIAT, in Cali (Colombia). In 2003, 28 lines from this cross were introduced in Brazil and multiplied in greenhouse. In the winter growing season of 2004, in Santo Antônio de Goiás (GO), these lines were multiplied in the field and in 2005, line LMC 205202963 (OXI-16) was selected for evaluations in field trials.

Thereafter, line LMC 205202963 was evaluated in 2006 in field trials. It was evaluated together with 135 other lines and 9 controls (IPR Juriti, Pérola, BRS Cometa, BRS Pontal, BRS Horizonte, IPR Colibri, Carioca Pitoco, Iapar 81 and BRS Requinte) in a triple lattice design, in plots of two 4-m rows. The tests were installed in Ponta Grossa (PR) in the rainy growing season and in Santo Antônio de Goiás in the winter. These tests evaluated seed yield, angular leaf spot reaction, plant architecture, and lodging tolerance.

In 2007, under the name CNFC 15097, the line was evaluated in a preliminary test with carioca lines, in a triple lattice design, in plots of two 4-m rows, along with 76 other lines and four controls (IPR Juriti, Pérola, BRS Cometa and BRS Pontal), in four environments: Santo Antônio de Goiás (GO) and Lavras (MG) in the winter; and Ponta Grossa (PR) and Passo Fundo (RS) in the rainy season. These tests evaluated the seed yield, plant architecture, lodging tolerance, and reaction to naturally occurring diseases (rust, anthracnose, angular leaf blight, common bacterial blight and powdery mildew).

In 2009, CNFC 15097 was evaluated in an Intermediate Test, with 27 other lines and four controls (BRS Estilo, Pérola, IRP Juriti and BRS Cometa), in a randomized block design with three replications, in plots of four 4-m rows. The trials were installed in eight environments: Santo Antônio de Goiás (GO), Sete Lagoas (MG), Ijaci (MG) and Uberlândia (MG), in the winter growing season; Ponta Grossa (PR), in two evaluations in the rainy and one test in the dry growing season; and Carira (SE), in the rainy season. These tests assessed: seed yield, 100seed weight, plant architecture, lodging tolerance, cycle, and disease reaction (angular leaf spot and common bacterial blight). Based on the results of the joint analyses of seed yield data and other agronomic traits, line CNFC 15097 was included in the VCU tests.

In 2010, seeds were multiplied to prepare the VCU tests. In 2011 and 2012, line CNFC 15097 was evaluated in 79 environments, along with 13 other lines and three controls (BRS Sublime, BRS Estilo, and Pérola), in a randomized block design with three replications, in four 4-m rows, using the recommended technologies for the respective environments and cropping systems. In the VCU trials, the line was extensively tested and the following traits were assessed: seed yield, sieve yield, 100-seed weight, visual seed appearance, cooking time, and protein content.

On a score scale from 1 (totally favorable) to 9 (totally unfavorable phenotype) (Melo, 2009), the following traits were also evaluated: plant architecture, lodging tolerance and reaction to the diseases common bacterial blight (Xanthomonas axonopodis pv. phaseoli); 
bacterial wilt (Curtobacterium flaccumfaciens pv flaccumfaciens); angular leaf spot (Pseudocercospora griseola); anthracnose (Colletotrichum lindemutianum); rust (Uromyces appendiculatus); fusarium wilt (Fusarium oxysporum sp. phaseoli); bean common mosaic virus (BCMV) and bean golden mosaic virus (BGMV). In addition, the seed yield was evaluated in a system without mineral nitrogen fertilization and with rhizobium inoculation.

Seed yield was measured (in $\mathrm{kg} \mathrm{ha}^{-1}$ ) and the seed moisture content corrected to $13 \%$. The sieve yield was measured as follows: a 300-g sample per plot was sifted through 4.5-mm-width, oblong holes (sieve 12); the seeds retained in the sieve were weighed and the result divided by the initial sample weight. From the retained seeds, another sample of 100 seeds was taken to determine the 100 -seed weight. From the test with best results (highest mean yields and lowest variation coefficient), samples were taken to determine the cooking time and protein content. For the cooking time, the seeds were soaked in distilled water at a 1:4 ratio $(\mathrm{w} / \mathrm{v})$ at room temperature. After 16 hours, the water was removed and the seeds placed in a Mattson cooker. The cooking time was determined as the period from the boiling point until the needles of the Mattson cooker penetrated $50 \%+1$ seeds. The protein content of the seed meal (beans ground in a ball mill) was analyzed and the nitrogen content was determined by the micro Kjeldahl method.

\section{Grain yield and yield potential}

In 79 VCU trials conducted in 2011 and 2012, in the rainy season in Sergipe, Alagoas and Pernambuco; in the dry and rainy seasons in Mato Grosso do Sul, São Paulo, Santa Catarina and Paraná; and in the, dry and winter sowing seasons in Goiás, Distrito Federal, Mato Grosso and Bahia; the cultivar BRS FC406 (CNFC 15097) produced equal to the control BRS Estilo (Table 1) and Pérola. In the three cultivation regions for common beans, the overall mean compared to BRS Estilo and Pérola was equal, showing the high seed yield of BRS FC406. In the rainy season in Region II (Mato Grosso, Goiás/Distrito Federal, Minas Gerais, Rio de Janeiro, Espírito Santo, Bahia, Tocantins and Maranhão), BRS FC406 presents $19.0 \%$ of superiority in relation to BRS Estilo, which is the most widely used cultivar in this season in central Brazil. This crop season in this region of Brazil represents approximately $18 \%$ of the national common bean production (402,000 tons), demonstrating the large potential market that BRS FC406 can supply. In the others growing seasons/regions, BRS FC406 presents seed yield similar to BRS Estilo and Pérola, showing high adaptability and seed.

Table 1. Seed yield $\left(\mathrm{kg} \mathrm{ha}^{-1}\right)$ of BRS FC406 compared to BRS Estilo in the tests of Value for Cultivation and Use, for each cultivation region and sowing season, in 2011 and 2012.

\begin{tabular}{ccccc}
\hline Region & Season & BRS FC406 & BRS Estilo & $\begin{array}{c}\text { Number of } \\
\text { environments }\end{array}$ \\
\hline I & Rainy & $2,908 \mathrm{a}$ & $3,075 \mathrm{a}$ & $\mathbf{1 9}$ \\
\hline & Dry & $2,387 \mathrm{a}$ & $2,319 \mathrm{a}$ & $\mathbf{1 3}$ \\
\hline II & Overall & $2,696 \mathrm{a}$ & $2,768 \mathrm{a}$ & $\mathbf{3 2}$ \\
\hline & Rainy & $1,868 \mathrm{a}$ & $1,568 \mathrm{~b}$ & $\mathbf{1 4}$ \\
\hline & Dry & $1,860 \mathrm{a}$ & $1,736 \mathrm{a}$ & $\mathbf{6}$ \\
\hline III & Winter & $2,884 \mathrm{a}$ & $2,867 \mathrm{a}$ & $\mathbf{1 3}$ \\
\hline Overall & Overall & $2,267 \mathrm{a}$ & $2,110 \mathrm{a}$ & $\mathbf{3 3}$ \\
\hline & Rainy & $2,396 \mathrm{a}$ & $2,491 \mathrm{a}$ & $\mathbf{1 4}$ \\
\hline
\end{tabular}

Region I - RS, SC, PR, MS and SP; Region II - MG, ES, RJ, GO, DF, MT, TO, BA and MA; Region III - SE, AL, PE, PB, CE, RN and PB. Means followed by the same letter, in lines, did not differ statistically from each other by the Scott-Knott method at $5 \%$ probability. 
In general, BRS FC406 performed better than BRS Estilo, the control with highest mean, in $53 \%$ of the evaluated environments, suggesting that BRS FC406 is a broadly adapted cultivar that can be grown advantageously in the main common bean-producing regions of Brazil. The overall yield mean of BRS FC406 was 2,463 $\mathrm{kg} \mathrm{ha}^{-1}$, compared to $2,405 \mathrm{~kg} \mathrm{ha}^{-1}$ of the control BRS Estilo. In a system with biological nitrogen fixation (BNF), the mean yield of BRS FC406 was $2,287 \mathrm{~kg} \mathrm{ha}^{-1}$, compared to 2,131 of Pérola, the best-performing control. The yield potential of BRS FC406, averaged across the five tests with highest yields of this cultivar, was $4,472 \mathrm{~kg}$ $\mathrm{ha}^{-1}$. This estimate indicates the promising genetic potential of the cultivar and that high yields can be achieved in favorable environments and under good growing conditions.

\section{Other traits}

With regard to the technological and industrial seed quality, cultivar BRS FC406 has a regular seed color and size. The seeds have a similar color to that of cultivar Pérola. The sieve yield of $79 \%$ and mean 100 -seed weight of 28.0 grams, in tests without fungicide application, are superior to those of the cultivars BRS Estilo and Pérola (Table 2), which are market standards for these traits, indicating high commercial value of the seeds of this cultivar. The mean cooking time of BRS FC406 was 35 min, slightly longer than that of Pérola and longer than that of BRS Estilo. In terms of the protein percentage, the mean content of BRS FC406 was identical to Pérola, superior to BRS Estilo.

Under artificial inoculation, cultivar BRS FC406 is resistant to common mosaic virus. In the field tests, it was moderately resistant to anthracnose and rust and moderately susceptible to angular leaf spot and Fusarium wilt. On the other hand, it was susceptible to common bacterial blight, bacterial wilt, and golden mosaic (Table 3).

Table 2. Characteristics of seeds of common bean cultivar BRS FC406, compared to those of BRS Estilo, Pérola and BRS Sublime.

\begin{tabular}{lcccc}
\hline Cultivar & $\begin{array}{c}\text { Cooking time } \\
(\text { minutes })\end{array}$ & $\begin{array}{c}\text { Protein content } \\
(\%)\end{array}$ & $\begin{array}{c}\text { Sieve yield } \\
(\%)^{*}\end{array}$ & $\begin{array}{c}\text { 100-seed weight } \\
(\mathbf{g})^{*}\end{array}$ \\
\hline BRS FC406 & $35.0 \mathrm{c}$ & $23.4 \mathrm{~b}$ & $79.0 \mathrm{a}$ & $28.0 \mathrm{a}$ \\
\hline BRS Estilo & $25.0 \mathrm{a}$ & $22.7 \mathrm{c}$ & $71.0 \mathrm{~b}$ & $25.4 \mathrm{c}$ \\
\hline Pérola & $31.0 \mathrm{~b}$ & $23.6 \mathrm{~b}$ & $67.0 \mathrm{c}$ & $26.2 \mathrm{~b}$ \\
\hline BRS Sublime & $26.0 \mathrm{a}$ & $24.3 \mathrm{a}$ & $70.0 \mathrm{~b}$ & $24.8 \mathrm{c}$ \\
\hline
\end{tabular}

*Estimate established in experiments without disease control, using sieve 12 (4.5 mm). Means followed by the same letter did not differ statistically from each other by the Scott-Knott method at $5 \%$ probability.

Table 3. Agronomic traits and disease reaction of cultivar BRS FC406, compared to the controls BRS Estilo, Pérola and BRS Sublime with carioca beans.

\begin{tabular}{lcccccccccc}
\hline Cultivar & Cycle & ARCH & AN & CBB & RU & ALF & CM & GM & FOP & BW \\
\hline BRS FC406 & N & Upright & MR & S & MR & MS & R & S & MS & S \\
\hline BRS Estilo & N & Upright & MS & S & MR & S & R & S & S & S \\
\hline Pérola & N & Semi-Prostrate & S & S & MR & MS & R & S & MS & S \\
\hline BRS Sublime & N & Upright & MS & S & MR & MR & R & S & S & S
\end{tabular}

ARCH- Plant architecture; AN- Anthracnose; CBB- Common bacterial blight; RU- Rust; ALF- Angular leaf spot; CM- Common mosaic; MD- Golden mosaic; FOP- Fusarium wilt; BW- Bacterial wilt; N-Normal Cycle; R- Resistant; MR- Moderately resistant; Moderately susceptible; S- Susceptible.

BRS FC406 has a normally cycle $(85-94$ days, from emergence to physiological maturity), similar to the cultivars BRS Estilo and Pérola
(Table 3). The plants have an upright architecture and an indeterminate growth habit type II. The cultivar has intermediate lodging tolerance and 
can be harvested mechanically, or even harvested and threshed in one operation (direct harvesting). The flowers are white and the pods reddish yellow at physiological maturity. At harvest maturity however, the pods are sand yellow. The seeds are light beige with light brown stripes, have a short oblong, reniform and rather flat shape and no gloss.

In comparison with BRS Estilo, which is the most commonly planted carioca seed cultivar of Embrapa in the rainy season, BRS FC406 has a higher seed yield, better anthracnose and angular leaf spot resistance, larger seed size and higher sieve yield. Thus, it is expected that BRS FC406 can be used on a large scale by common bean producers in Brazil and, more specifically, in the Central Region of Brazil, for cultivation in the rainy season.

\section{Seed production}

BRS FC406 is registered on 04/18/19, under number 39841, by the Ministry of Agriculture, Livestock and Supply (MAPA). Embrapa is in charge of the basic seed production.

\section{Conclusions}

The common bean cultivar BRS FC406 with carioca beans has a normal cycle, high yield potential, meets the commercial quality standard of the seeds, has yield stability and is resistant to anthracnose and angular leaf spot. The cultivar is widely adapted to the distinct regions of common bean cultivation. Moreover, the yields of the cultivar in the rainy season in central Brazil are excellent.

BRS FC406 is indicated for sowing in the following states and growing seasons: rainy, dry and winter growing seasons in Goiás, Distrito Federal, Espírito Santo, Rio de Janeiro, Bahia, Mato Grosso and Tocantins (Region II); rainy and dry seasons in Mato Grosso do Sul, Paraná, Santa Catarina, São Paulo and Rio Grande do Sul (Region I); and rainy seasons in Maranhão, Sergipe, Alagoas, Pernambuco, Rio Grande do Norte, Piauí, Ceará and Paraíba (Region III).

\section{Acknowledgements}

The authors are indebted to the International Center for Tropical Agriculture (CIAT), for providing the line for evaluation in Brazil as well as the documentation authorizing Embrapa to register the cultivar. They also wish to thank the partner institutions in the evaluation of the cultivar: Embrapa Rice and Beans; Secretariat of Innovation and Business of Embrapa, Embrapa Coastal Tablelands; Embrapa Western Agriculture; Company of Agricultural Research and Rural Extension of Mato Grosso; Instituto Agronômico de Pernambucano; Emater Alagoas; Emater Goiás; University of Rio Verde; Uni-Anhanguera; Embrapa Cerrados; Embrapa Maize and Sorghum; Federal University of Lavras; Federal University of Uberlândia; Embrapa Soybean; Federal University of Mato Grosso do Sul; Mato Grosso do Sul State University.

\section{References}

FAO - Food and Agriculture Organization of the United Nations. 2020. Available at:http://www.fao.org/faostat/en/\#data/QC/visualize/. Acessed on March, 24, 2020.

EMBRAPA ARROZ E FEIJÃO, 2019. Dados conjunturais da produção de feijão (Phaseolus vulgaris L.) e caupi (Vigna unguiculata (L.) Walp) no Brasil: 1985 a 2017. Available at: http://www.cnpaf.embrapa.br/socioeconomia/index.htm. Accessed on January 05, 2019.

FARIA, L.C.; MELO. P.G.S.; PEREIRA, H.S.; DEL PELOSO, M.J.; BRAS, A.J.B.P.; MOREIRA, J.A.A.; CARVALHO, H.W.L.; MELO, L.C. 2013. Genetic progress during 22 years of improvement of carioca-type common bean in Brazil. Field Crops Research, 142:68-74. 
MELO, L.C. 2009. Procedimentos para condução de ensaios de valor de cultivo e uso em feijoeirocomum. Santo Antônio de Goiás: Embrapa Arroz e Feijão. 104p. (Embrapa Arroz e Feijão. Documentos, 239).

MELO, L.C.; DEL PELOSO, M.J.; PEREIRA, H.S.; FARIA, L.C.; COSTA, J.G.C.; DÍAZ, J.L.C.; RAVA, C.A.; WENDLAND, A.; ABREU, A.F.B. 2010. BRS Estilo - Common bean cultivar with Carioca grain, upright growth and high yield potential. Crop Breeding and Applied Biotechnology, 10:377-379.

MELO, L.C.; PEREIRA, H.S.; FARIA, L.C.; SOUZA, T.L.P.O.; WENDLAND, A.; DÍAZ, J.L.C.; CARVALHO, H.W.L.; MELO, C.L.P.; COSTA, A.F.; MAGALDI, M.C.S.; COSTA, J.G.C. 2017. BRS FC402: high-yielding common bean cultivar with carioca grain, resistance to anthracnose and fusarium wilt. Crop Breeding and Applied Biotechnology, 17: 67-71.

PEREIRA, H.S.; WENDLAND, A.; MELO, L.C.: DEL PELOSO, M.J.; FARIA, L.C.; COSTA, J.G.C.; NASCENTE, A.S.; DÍAZ, J.L.C.; CARVALHO, H.W.L.; ALMEIDA, V.M.; MELO, C.L.P.; COSTA, A.F.; POSSE, S.C.P.; SOUZA, J.F.; ABREU, A.F.B.; MAGALDI, M.C.S.; GUIMARÃES, C.M.; OLIVEIRA, J.P. 2012. BRS Notável: a medium-early-maturing, diseaseresistant Carioca common bean cultivar with high yield potential. Crop Breeding and Applied Biotechnology, 12: 220-223.

WENDLAND, A.; PEREIRA, H.S.; FARIA, L.C.; SOUZA, T.L.P.O.; DEL PELOSO, M.J.; COSTA, J.G.C.; DÍAZ, J.L.C.; MAGALDI, M.C.S.; ALMEIDA, V.M.; CARVALHO, H.W.L.; MELO, C.L.P.; COSTA, A.F.; ABREU, A.F.B.; MELO, L.C. 2018. BRS Sublime: Common bean cultivar with carioca grain, resistance to angular leaf spot and high nutritional quality. Crop Breeding and Applied Biotechnology, 18: 440-445. 